\title{
PENGARUH PARSIAL DAN SIMULTAN VARIABEL BEBAS TERHADAP KEPUASAN PELANGGAN TRANSPORTASI ONLINE KOTA PALEMBANG
}

\author{
Kurniati $^{1}$ \\ Universitas Bina Darma, Palembang ${ }^{1}$ \\ Email: ${ }^{1}$ kurniati@binadarma.ac.id
}

(Naskah masuk: 25 Oktober 2018, diterima untuk diterbitkan: 02 Oktober 2019)

\begin{abstract}
Abstrak
Bisnis jasa berbasis online semakin berkembang dalam memenuhi kebutuhan hidup masyarakat. Hal terpenting dari penerapan bisnis ini adalah menciptakan kepuasan terhadap konsumen. Transportasi online merupakan salah satu bisnis yang berkembang pesat di kalangan masyarakat kota Palembang dalam dua tahun terakhir ini. Dimana dalam penerapannya, pengguna harus terlebih dahulu melakukan download dan install aplikasi melalui aplikasi play store menggunakan smart phone android. Masyarakat kota Palembang untuk saat ini telah banyak menggunakan aplikasi GO-JEK dan aplikasi GRAB. Penelitian ini dilakukan untuk mengukur pengaruh kualitas layanan dan harga terhadap kepuasan pelanggan transportasi online masyarakat kota Palembang. Dengan demikian penulis dapat mengetahui pengaruh secara parsial dan simultan terhadap kepuasan pelanggan jasa transportasi online pada konsumen aplikasi GO-JEK terhadap prosfek jasa transportasi online di kota Palembang. Teknik nonprobability sampling dengan menggunakan pendekatan accidental sampling menggunakan metode survei melalui angket yang diisi oleh responden untuk melihat pengaruh parsial dan simultan pada dua variabel terhadap keputusan penggunaan layanan.
\end{abstract}

Kata kunci: Transportasi online, GO-JEK, accidental sampling.

\section{EFFECT OF PARTIAL AND SIMULTANEOUS FREE VARIABLES ON CUSTOMER SATISFACTION ONLINE TRANSPORTATION IN PALEMBANG CITY}

\begin{abstract}
Online-based business services are growing in meeting the needs of people's lives. The most important goal of this business is to create customer satisfaction. Online transportation is one of the fastest growing business among the people of Palembang city in the last two years. Where in the application, the user must first download and install the application through the application play store using smart phone android. The people of Palembang city to date have been using many applications of GO-JEK and GRAB applications. This study was conducted to measure the effect of service quality and price on customer satisfaction of online transportation of Palembang city community. Thus the authors can know the effect of partial and simultaneous on customer satisfaction of online transportation services on consumer applications GO-JEK against prosfek online transportation services in the city of Palembang. Nonprobability sampling technique using accidental sampling approach using survey method through questionnaire filled by respondent to see partial and simultaneous influence on two variables to service use decision.
\end{abstract}

Keywords: Online Transport, GO-JEK, accidental sampling.

\section{PENDAHULUAN}

Dalam penelitian ini, penulis melakukan penelitian terhadap pengaruh variabel kualitas layanan dan harga terhadap kepuasan pelanggan dibandingkan dengan jasa transportasi konvensional. Faktor utama penentu kepuasan pelanggan adalah persepsi pelanggan terhadap kualitas jasa dan harga. Menurut Kusumasitta (2014), dimensi kualitas layanan terdiri dari 10 dimensi yaitu reliability, responsiveness, competence, acces, courtesy, communication, credibility, security, understanding/ knowing the customer, dan tangibles dimana secara signifikan berpengaruh terhadap kepuasan yang didapat oleh pelanggan.

Transportasi online dan transportasi konvensional di Palembang menagalami persaingan 
baik secara tarif, standar pelayanan, jam operasional dan dari sisi lainnya. Transportasi konvensional seperti Bluebird yang semula pemesanan dilakukan secara manual atau via telepon telah bergabung dengan perusahaan penyedia aplikasi jasa angkut online yaitu PT Gojek. Namun, masyarakat Palembang telah lebih dahulu merasakan manfaat dari transportasi online Go-Jek dan Go-Car yang berasal dari PT Gojek Indonesia yang telah berdiri sejak tahun 2010. Manfaat yang dirasakan konsumen saat menggunakan fasilitas aplikasi transportasi online adalah tahun keluar kendaraan yang mendaftar sebagai driver minimal keluaran tahun 2000, pada aplikasi tertera data diri driver dan GPS untuk melacak keberadaan para drivernya. Sebagai pelanggan khusus kendaraan roda dua telah dipersiapkan helm dan asuransi keselamatan untuk semua pengguna jasa transportasi online. Proses pemesanan dapat dilakukan dengan mudah yaitu dengan melakukan order melalui aplikasi melalu smart phone. Pada aplikasi terdapat layanan pengaduan dan pada akhir pelayanan pelanggan dapat memberikan review dan rating untuk driver tentang pelayanan yang sudah didapatkannya. Perusahaan dapat melakukan penilaian terhadap pelayanan yang telah didapatkan oleh konsumen. Sehingga, perusahaan dapat terus melakukan memperbaiki terhadap standar pelayanannya.

Dari uraian di atas, penelitian ini dilakukan guna mengukur pengaruh kualitas layanan dan harga terhadap kepuasan pelanggan transportasi online masyarakat kota Palembang. Dengan melakukan beberapa pengujian melalui program SPSS Versi 23, untuk melihat seberapa besar pengaruh parsial dan simultan terhadap kepuasan pelanggan jasa transportasi online, dengan teknik nonprobability sampling menggunakan pendekatan accidental sampling melalui metode survei dengan penyebaran angket yang diisi oleh responden terhadap keputusan penggunaan layanan.

\section{PENELITIAN YANG TERKAIT}

Adapun penelitian-penelitian yang relevan dengan penelitian ini dan dijadikan sebagai referensi untuk melakukan penelitian ini antara lain adalah:

1. Analisis Penerapan Teknologi Komunikasi Tepat Guna Pada Bisnis Transportasi Ojek Online yang dilakukan oleh W.Anindhita, M. Arisanty dan D. Rahmawati, (2016). Berdasarkan analisis dan pembahasan masalah yang berhubungan dengan penerapan teknologi komunikasi tepat guna pada bisnis transportasi ojek online, maka penulis dapat mengambil kesimpulan yaitu:

a. Dengan adanya teknologi komunikasi tepat guna pada bisnis transportasi ojek online maka, masyarakat saat ini sangat dimudahkan terutama dalam pemesananya cepat dan real time yaitu hanya dengan melakukan order menggunakan aplikasi yang terhubung dengan media internet.

b. Kehadiran Gojek online memberikan kontribusi yang sangat signifikan bagi kehidupan sosial msyarakat karena dapat memberikan perubahan sosial dan mindset tentang ojek online seperti peralihan penggunaan teknologi sebagai sarana transportasi umum, peningkatan citra transportasi Ojek sebagai sarana transportasi yang solutif, cepat, bebas macet, aman dan nyaman.

2. Pengaruh Kualitas Layanan Dan Kepuasan Konsumen Terhadap Kinerja Ojek Online yang dilakukan oleh Ana Rahmadhayanti, berdasarkan analisis dan pembahasan masalah yang berhubungan dengan judul penelitian di atas yaitu:

a. Kepuasan konsumen menggunakan jasa Go-Jek berpengaruh secara positif dan signifikan terhadap Kinerja Ojek online.

b. Kualitas Layanan Go-Jek berpengaruh secara positif dan signifikan terhadap Kinerja Ojek online.

c. Dengan adanya alat transportasi ojek Online, diharapkan agar kedepannya tercipta juga alat transportasi lain yang tidak kalah dengan transporatsi saat ini.

d. Keefektifan GOJEK sebagai alat transportasi saat ini memiliki keunggulan tersendiri dibandingkan dengan alat transportasi yang lainnya.

e. Dengan adanya kemudahan pemesanan Go-Jek lewat Smartphone diharapkan kedepanya tidak disalah artikan untuk maksud-maksud tertentu, misalnya tidak kejahatan maupun kriminal.

\section{METODE PENELITIAN}

Pada penelitian ini, jenis penelitian yang digunakan adalah penelitian deskriptif dengan pendekatan kuantitatif. Menurut Warjiyono \& Mei.C.H., (2018), metode deskriptif adalah metode yang bisa digunakan untuk survey guna mendapatkan data yang telah terjadi pada masa lampau atau masa kini tentang pendapat, perilaku, keyakinan untuk menguji beberapa hipotesis. Menurut Kurniati (2018), Metode kuantitatif menekankan fenomena-fenomena objektif dan dikaji secara kuantitatif. Maksimalisasi objektivitas desain penelitian ini dilakukan dengan menggunakan angka-angka, pengolahan statistik, struktur dan percobaan terkontrol. 


\subsection{Metode Analisis}

Metode analisis yang digunakan dalam penelitian ini adalah metode analisis regresi linier berganda. Analisis regresi berganda merupakan pengembangan dari analisis sederhana yang berguna untuk meramalkan nilai variabel terikat (Y) apabila variabel bebas minimal dua atau lebih. [3]

Dengan kata lain analisis regresi ganda ialah suatu alat analisis peramalan nilai pengaruh dua variabel bebas atau lebih terhadap variabel terikat untuk membuktikan ada atau tidaknya hubungan fungsi atau hubungan kausal antara dua variabel bebas atau lebih (X1), (X2), (X3)... (Xn) dengan satu variable terikat.

\subsection{Populasi dan Sampling}

Menurut Sugiyono (2014), populasi adalah wilayah generalisasi yang terdiri dari objek atau subjek yang mempunyai kualitas dan karakteristik tertentu yang ditetapkan oleh peneliti untuk dipelajari dan kemudian ditarik kesimpulannya. Jumlah populasi dalam penelitian ini adalah lebih dari 5.000 pelanggan. Teknik pengambilan sampel yang digunakan dalam penelitian adalah menggunkan metode non probability sampling dengan metode pengambilan sampel yang digunakan adalah accidental sampling.

Nonprobability sampling adalah teknik sampling yang tidak memberi peluang pada populasi untuk menjadi anggota sampel. Sedangkan accidental sampling adalah teknik penentuan sampel berdasarkan spontanitas, artinya siapa saja yang secara tidak sengaja bertemu dan sesuai dengan karakteristik (ciri-cirinya) maka orang tersebut dapat digunakan sebagai sampel (responden). [3] Untuk memudahkan penelitian jumlah sampel yang diambil ditentukan dengan rumus Slovin seperti di bawah ini:

$n=\frac{N}{1+N(d)^{2}}$

Keterangan:

$n=$ ukuran sampel

$\mathrm{N}=$ ukuran populasi

$d=$ tingkat kesalahan yang dipilih (1\%, 5\% dan 10\%)

Berdasarkan rumus di atas, dalam penelitian ini apabila jumlah $\mathrm{N}$ adalah 5.000 pengguna, denganingkat kesalahan penarikan sampel ditentukan sebesar 5\%. Maka dari perhitungan rumus tersebut dapat diperoleh sampel yang dibutuhkan, yaitu:

$n=\frac{N}{1+N(d)^{2}}=\frac{5000}{1+5000(0.05)^{2}}=370,37$

Jadi berdasarkan rumus di atas, sampel diambil sebanyak 370,37 orang responden. Untuk memudahkan perhitungan maka dibulatkan menjadi 370 orang responden.

\subsection{Instrumen Penelitian}

Instrumen penelitian yang digunakan dalam penelitian ini adalah kuesioner dengan peyebaran melalui media elektronik dengan menggunakan fasilitas yang terdapat pada google drive. Berikut merupakan isi dari kuesioner yang digunakan dalam penelitian ini:

Tabel 1. Isi Kuesioner

\begin{tabular}{|c|c|c|}
\hline Variabel & Indikator & Pernyataan \\
\hline $\begin{array}{l}\text { Kualitas } \\
\text { Layanan } \\
\left(\mathrm{X}_{1}\right)\end{array}$ & $\begin{array}{l}\text { Berwujud } \\
\text { (tangible) }\end{array}$ & $\begin{array}{ll}\text { 1. } & \text { Transportasi online } \\
\text { menggunakan kendaraan } \\
\text { yang layak jalan dan tidak } \\
\text { di modifikasi. }\left(\mathrm{X}_{1.1 .1}\right)\end{array}$ \\
\hline
\end{tabular}

2. Transportasi online memberikan perlengkapan
keamanan berkendara keamanan berkendara
seperti helm dan masker untuk digunakan oleh konsumen khususnya kendaraan online roda dua. $\left(\mathrm{X}_{1.1 .2}\right)$

3. Transportasi online menggunakan identitas perusahaan misalnya berupa jaket dan helm khusus kendaraan online roda dua. $\left(\mathrm{X}_{1.1,3}\right)$

4. Transportasi online berpakaian dengan rapi dan bersepatu saat melakukan pelayanan kepada konsumen.

(X1.1.4)

Keandalan 1. Ada pemberitahuan dengan (Reliability) jelas apabila terjadi keterlambatan pelayanan kepada pelanggan. $\left(\mathrm{X}_{1.2 .1}\right)$

2. Transportasi online mengemudikan kendaraannya dengan manaati peraturan tata tertib berlalu lintas. $\left(\mathrm{X}_{1.2 .2}\right)$

3. Transportasi online mengenakan tarif sesuai dengan harga yang tertera pada aplikasi keandaraan online. $\left(\mathrm{X}_{1.2 .3}\right)$

4. Kendaraan online memberikan pelayanan selama 24 jam. $\left(\mathrm{X}_{1.2 .4}\right)$

5. Transportasi online memberikan kemudahan dalam melakukan pemesanan. $\left(\mathrm{X}_{1.2 .5}\right)$

Daya tanggap (Responsive ness) Transportasi online mengkonfirmasi order konsumen secara cepat dengan menelfon konsumen untuk memastikan. (X1.3.1)

2. Driver transportasi online segera datang setelah pelanggan melakukan order melalui aplikasi kendaraan online. (X1.3.2) Driver dan Staff transportasi online cepat dalam menanggapi keluhan pelanggan. (X1.3.3) 
552 Jurnal Teknologi Informasi dan Ilmu Komputer (JTIIK), Vol. 6, No. 4, Oktober 2019, hlm. 549-558

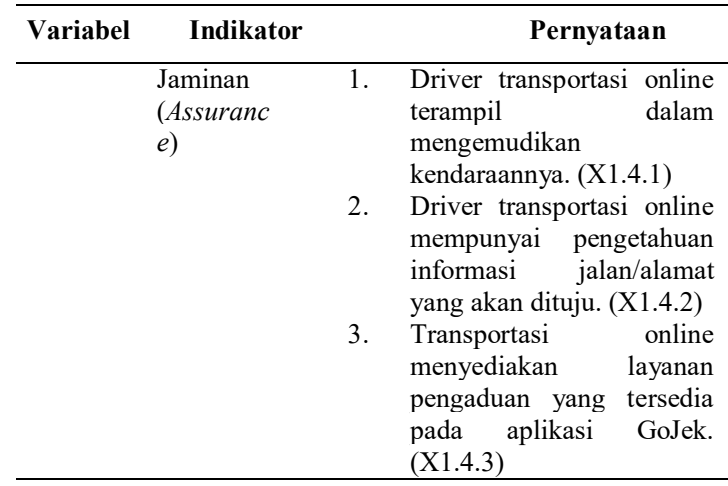

Tabel 2. isi kuesioner lanjutan

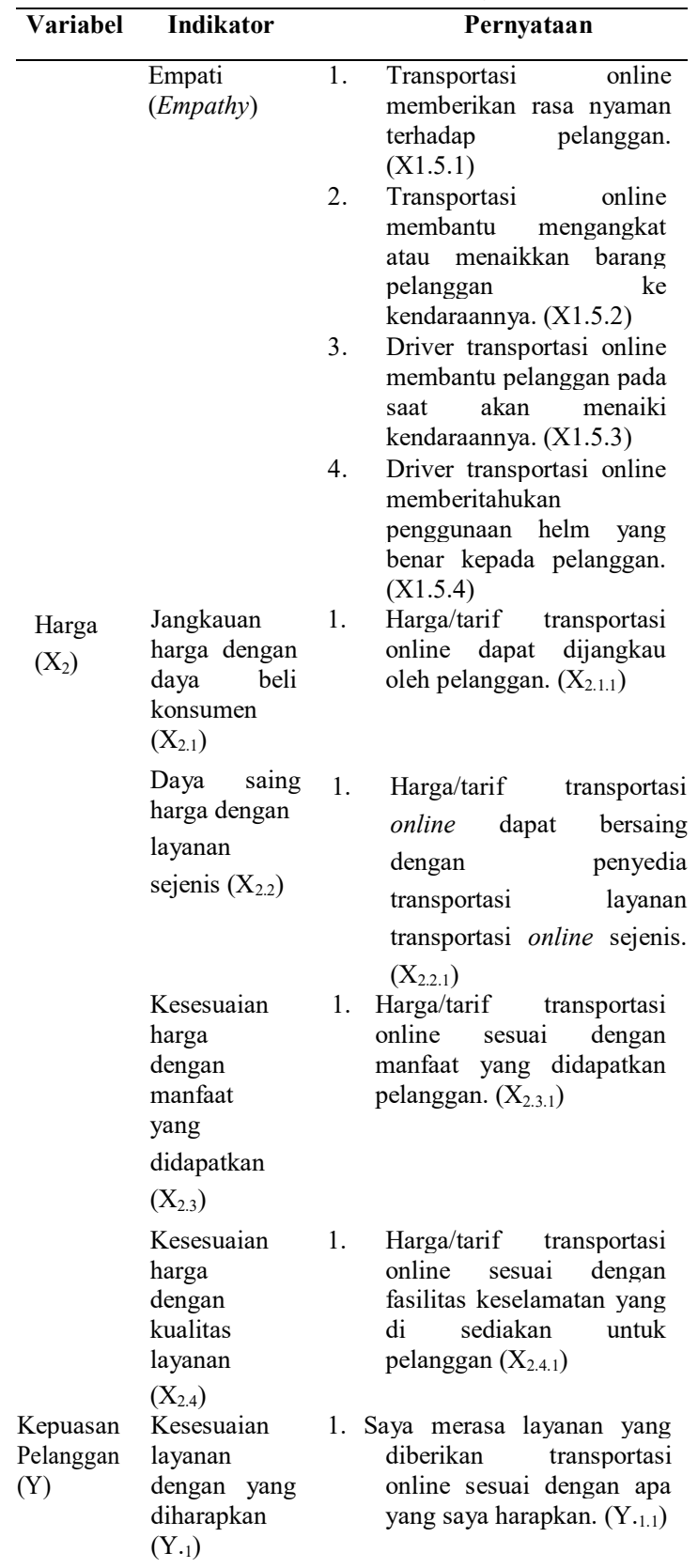

\begin{tabular}{|c|c|c|}
\hline Variabel & Indikator & Pernyataan \\
\hline & $\begin{array}{l}\text { Kesesuaian } \\
\text { layanan } \\
\text { dengan } \\
\text { harga/tarif } \\
\text { yang } \\
\text { dibayarkan }\left(\mathrm{Y}_{\cdot 2}\right)\end{array}$ & $\begin{array}{l}\text { 1. Saya merasa layanan yang } \\
\text { diberikan transportasi } \\
\text { online sesuai dengan } \\
\text { harga/tarif yang saya } \\
\text { bayarkan. }\left(\mathrm{Y}_{\cdot 2.1}\right)\end{array}$ \\
\hline & $\begin{array}{l}\text { Kepuasan } \\
\text { penumpang } \\
\text { akan layanan } \\
\text { yang } \\
\text { ditawarkan } \\
(\mathrm{Y} .3)\end{array}$ & 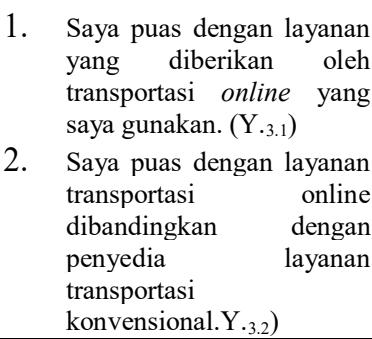 \\
\hline
\end{tabular}

Menurut A. H. Saepul (2014), skala likert yang benar adalah yang pokoknya memuat nilai atau arah dan responden mengindikasikan persetujuan atau pertentangan pada pernyataan. Skala likert menyediakan fleksibilitas yang tinggi karena petunjuk skala dapat beragam sesuai dengan kealamian pertanyaan atau pernyataan.

Menurut E. W. Putro (2013), skala netral tidak digunakan dalam penelitian ini dikarenakan untuk memperoleh jawaban pasti dari responden terkait sikap serta pendapat sebagai pelanggan. Adanya skala netral akan mengakibatkan seorang responden mempunyai kecendrungan memilih alternatif netral sebagai pilihan yang paling aman, terutama bagi seorang responden yang ragu untuk memilih jawaban. Dengan lima skala yang digunakan bermaksud untuk menghasilkan sikap responden yang lebih akurat.

\subsection{Uji Instrumen}

Uji instrumen dalam penelitian ini dilakukan melalui uji reliabilitas dan uji validitas. Uji reliabilitas dan uji validitas dilakukan dengan mengambil 370 responden. Menurut P. Santiari \& I. Rahayuda (2018), mengatakan bahwa uji validitas dilakukan apabila indikator alat ukur berada $<\mathrm{r}$ tabel (tidak valid) dan $>\mathrm{r}$ tabel (valid). Dapat disimpulkan bahwa hal ini dilakukan dengan tujuan tidak lain hanya untuk mengetahui pertanyaan mana yang valid maupun yang tidak valid, dengan mengkonsultasikan data tersebut dengan tingkat signifikan $\mathrm{r}$ tabel apabila alat ukur tersebut berada $<$ $\mathrm{r}$ tabel (tidak valid). Pengujian statistik mengacu pada kriteria: $r$ hitung $<\mathrm{r}$ tabel maka tidak valid sedangkan $r$ hitung $>\mathrm{r}$ tabel maka valid. Dengan menggunakan program SPSS IBM Versi 23 for windows diperoleh hasil reliabilitas sebagai berikut: 
Tabel 3. Uji Reliabilitas Instrumen

\begin{tabular}{cccc}
\hline Item & $\begin{array}{c}\text { Nilai } \\
\text { Cronbach's } \\
\text { Alpha }\end{array}$ & $\begin{array}{l}\text { Nilai } \\
\text { Kritis }\end{array}$ & Keterangan \\
\hline $\mathrm{X}_{1}$ & .899 & 0,60 & Reliabel \\
$\mathrm{X}_{2}$ & .721 & 0,60 & Reliabel \\
$\mathrm{Y}$ & .733 & 0,60 & Reliabel \\
\hline
\end{tabular}

Berdasarkan tabel 2 nilai croanbach's alpha dari semua item instrumen tersebut lebih dari 0,60. Sehingga, dapat disimpulkan bahwa semua item instrumen atau angket yang digunakan sudah reliabel dan layak digunakan untuk mengumpulkan data. Dengan menggunakan program SPSS IBM Versi 23 for windows diperoleh hasil validitas sebagai berikut:

\begin{tabular}{|c|c|c|c|}
\hline Item & $\begin{array}{c}\text { Pearson } \\
\text { Correlatin }\end{array}$ & Sig Hitung & Keterangan \\
\hline \multicolumn{4}{|c|}{ Kualitas Layanan $\left(\mathrm{X}_{1}\right)$} \\
\hline $\mathrm{X}_{1.1 .1}$ & 0,434 & 0.082 & 0,000 \\
\hline $\mathrm{X}_{1.1 .2}$ & 0,547 & 0.082 & 0,000 \\
\hline $\mathrm{X}_{1.1 .3}$ & 0,578 & 0.082 & 0,000 \\
\hline $\mathrm{X}_{1.1 .4}$ & 0,564 & 0.082 & 0,000 \\
\hline $\mathrm{X}_{1.2 .1}$ & 0,610 & 0.082 & 0,000 \\
\hline $\mathrm{X}_{1.2 .2}$ & 0,596 & 0.082 & 0,000 \\
\hline $\mathrm{X}_{1.2 .3}$ & 0,451 & 0.082 & 0,000 \\
\hline $\mathrm{X}_{1.2 .4}$ & 0,582 & 0.082 & 0,000 \\
\hline $\mathrm{X}_{1.2 .5}$ & 0,570 & 0.082 & 0,000 \\
\hline $\mathrm{X}_{1.3 .1}$ & 0,617 & 0.082 & 0,000 \\
\hline $\mathrm{X}_{1.3 .2}$ & 0,641 & 0.082 & 0,000 \\
\hline $\mathrm{X}_{1.3 .3}$ & 0,614 & 0.082 & 0,000 \\
\hline $\mathrm{X}_{1.4 .1}$ & 0,642 & 0.082 & 0,000 \\
\hline $\mathrm{X}_{1.4 .2}$ & 0,442 & 0.082 & 0,020 \\
\hline $\mathrm{X}_{1.4 .3}$ & 0,616 & 0.082 & 0,000 \\
\hline $\mathrm{X}_{1.5 .1}$ & 0,660 & 0.082 & 0,000 \\
\hline $\mathrm{X}_{1.5 .2}$ & 0,643 & 0.082 & 0,000 \\
\hline $\mathrm{X}_{1.5 .3}$ & 0,640 & 0.082 & 0,000 \\
\hline $\mathrm{X}_{1.5 .4}$ & 0,618 & 0.082 & 0,000 \\
\hline \multicolumn{4}{|c|}{$\operatorname{Harga}\left(\mathrm{X}_{2}\right)$} \\
\hline $\mathrm{X}_{2.1 .1}$ & 0,736 & 0.082 & 0,000 \\
\hline $\mathrm{X}_{2.2 .1}$ & 0,715 & 0.082 & 0,000 \\
\hline $\mathrm{X}_{2.3 .1}$ & 0,752 & 0.082 & 0,000 \\
\hline $\mathrm{X}_{2.4 .1}$ & 0,723 & 0.082 & 0,000 \\
\hline \multicolumn{4}{|c|}{ Kepuasan Pelanggan (Y) } \\
\hline Y.1.1 & 0,770 & 0.082 & 0,000 \\
\hline Y.2.1 & 0,758 & 0.082 & 0,000 \\
\hline Y.3.1 & 0,742 & 0.082 & 0,000 \\
\hline Y.3.2 & 0,709 & 0.082 & $\mathbf{0 , 0 0 0}$ \\
\hline
\end{tabular}

Berdasarkan tabel 4 dapat dilihat bahwa semua nilai sig hitung dalam instrumen penelitian yang digunakan semuanya mempunyai nilai yang lebih kecil dari 0,05. Sehingga dapat disimpulkan bahwa semua indikator pada instrumen penelitian dinyatakan valid.

\subsection{Teknik Analisis Data}

Teknik analisis yang digunakan dalam penelitian ini terdiri dari:

1. Uji Asumsi Klasik

a. Menurut I. Ghozali (2013), uji Multikolinieritas bertujuan untuk menguji apakah model regresi ditemukan adanya korelasi antar variabel bebas (Independen Variable)".

b. Menurut A. Atmadjati (2018) uji Heteroskedastisitas tujuan dilakukannya uji heteroskedastisitas adalah untuk menguji apakah pada model regresi terjadi ketidaksamaan variance dari residual satu pengamatan ke pengamatan yang lain".

c. Menurut I. Ghozali (2013), Uji Normalitas menjelaskan bahwa "uji normalitas dilakukan untuk menguji kenormalan distribusi residual. Untuk mengetahui normalitas data dapat menggunakan analisis grafik dan uji statistik".

d. Menurut I. Ghozali (2013), Uji Linieritas menjelaskan bahwa "uji linieritas ini digunakan untuk melihat apakah spesifikasi model yang digunakan sudah benar aiau tidak".

2. Analisis Regresi Linier Berganda

Analisis regresi linear berganda adalah alat analisis peramalan nilai pengaruh dua variabel bebas atau lebih terhadap variabel terikat untuk membuktikan ada tidaknya hubungan fungsi atau kausal antara dua variabel bebas atau lebih dan satu variabel terikat. Persamaan umum regresi berganda sebagai berikut:

$$
\begin{gathered}
\mathrm{Y}=\mathrm{a}+\mathrm{b}_{1} \mathrm{X}_{1}+\mathrm{b}_{2} \mathrm{X}_{2} \\
\text { Keterangan: } \\
\mathrm{Y}=\text { Kepuasan Pelanggan } \\
\mathrm{a}=\text { Konstanta dari persamaan regresi } \\
\mathrm{b}_{1}=\text { Koefisien regresi dari } \\
\text { Kualitas Layanan } \\
\mathrm{X}_{1}=\text { Variabel } \\
\text { Kualitas Layanan } \\
\mathrm{b}_{2}=\text { Koefisien regresi dari } \\
\text { Harga Xariabel Harga } \\
\text { Variabe }
\end{gathered}
$$

3. Koofisien Determinasi $\left(\mathrm{R}^{2}\right)$ digunakan untuk mengetahui presentase sumbangan pengaruh variabel indepanden terhadap variabel dependen.

4. Uji Hipotesis

a. Menurut I. Ghozali (2013), uji t menjelaskan bahwa uji t digunakan untuk mengetahui seberapa jauh pengaruh satu variabel independen terhadap variabel dependen".

b. Menurut I. Ghozali (2013), uji F menjelaskan bahwa uji $\mathrm{F}$ digunakan untuk 
554 Jurnal Teknologi Informasi dan Ilmu Komputer (JTIIK), Vol. 6, No. 4, Oktober 2019, hlm. 549-558

mengetahui apakah variabel-variabel independen secara simultan berpengaruh terhadap variabel dependen".

\section{HASIL DAN PEMBAHASAN}

Karakteristik responden pada penelitian ini, dengan jumlah 370 responden ialah sebagai berikut:

\begin{tabular}{|c|c|c|c|}
\hline \multicolumn{2}{|c|}{ Karakteristik } & \multirow{2}{*}{$\begin{array}{c}\text { Jumlah } \\
161\end{array}$} & \multirow{2}{*}{$\begin{array}{c}\text { Persentase (\%) } \\
44 \%\end{array}$} \\
\hline & Laki-laki & & \\
\hline Kelamin & Perempuan & 209 & $56 \%$ \\
\hline \multirow[t]{4}{*}{ Usia } & $\leq 25$ Tahun & 165 & $45 \%$ \\
\hline & 26-35 Tahun & 141 & $38 \%$ \\
\hline & 36-40 Tahun & 64 & $17 \%$ \\
\hline & 41-55 Tahun & 0 & $0 \%$ \\
\hline \multirow[t]{3}{*}{ Status } & Dosen & 36 & $10 \%$ \\
\hline & Mahasiswa & 198 & $53 \%$ \\
\hline & Umum & 136 & $37 \%$ \\
\hline \multirow{3}{*}{$\begin{array}{l}\text { Lama } \\
\text { Interaksi }\end{array}$} & $<1$ thn & 99 & $27 \%$ \\
\hline & $>1$ thn & 265 & $72 \%$ \\
\hline & $\begin{array}{l}\text { Tidak } \\
\text { Pernah }\end{array}$ & 6 & $1 \%$ \\
\hline \multirow{4}{*}{$\begin{array}{l}\text { Lokasi } \\
\text { Pemesanan }\end{array}$} & Rumah & 59 & $16 \%$ \\
\hline & Kantor & 102 & $28 \%$ \\
\hline & Mobile & 198 & $53 \%$ \\
\hline & Lainnya & 11 & $3 \%$ \\
\hline \multirow{18}{*}{$\begin{array}{l}\text { Transportas } \\
\text { i online } \\
\text { yang } \\
\text { digunakan } \\
\text { Fasilita } \\
\text { s yang } \\
\text { diguna } \\
\text { kan }\end{array}$} & GOJEK & 302 & $82 \%$ \\
\hline & GRAB & 64 & $17 \%$ \\
\hline & Lainnya & 4 & $1 \%$ \\
\hline & $G O-R I D E$ & 155 & $42 \%$ \\
\hline & $G O-C A R$ & 103 & $28 \%$ \\
\hline & $G O-$ & & \\
\hline & BLUEBIRD & 4 & $1 \%$ \\
\hline & $G O-F O O D$ & 93 & $25 \%$ \\
\hline & $G O-S E N D$ & 11 & $3 \%$ \\
\hline & $G O-P U L S A$ & 4 & $1 \%$ \\
\hline & $G O-B I L L S$ & 0 & $0 \%$ \\
\hline & GO-SHOP & 0 & $0 \%$ \\
\hline & $G O-M A R T$ & 0 & $0 \%$ \\
\hline & $G O-T I X$ & 0 & $0 \%$ \\
\hline & $G O-B O X$ & 0 & $0 \%$ \\
\hline & $G O-C L E A N$ & & $0 \%$ \\
\hline & $G O-G L A M$ & 0 & $0 \%$ \\
\hline & $G O-A U T O$ & 0 & $0 \%$ \\
\hline
\end{tabular}

\begin{tabular}{|c|c|c|c|}
\hline \multicolumn{2}{|c|}{ Karakteristik } & Jumlah & Persentase (\%) \\
\hline \multirow{7}{*}{ Manfaat } & $G O-M E D$ & 0 & $0 \%$ \\
\hline & $\begin{array}{l}G O- \\
B U S W A Y\end{array}$ & 0 & $0 \%$ \\
\hline & $\begin{array}{l}\text { Menghemat } \\
\text { tenaga }\end{array}$ & 84 & $17 \%$ \\
\hline & $\begin{array}{l}\text { Efisiensi } \\
\text { waktu }\end{array}$ & 118 & $23 \%$ \\
\hline & $\begin{array}{l}\text { Harga tidal } \\
\text { mahal }\end{array}$ & 100 & $20 \%$ \\
\hline & Multifungsi & 169 & $33 \%$ \\
\hline & $\begin{array}{l}\text { Mengurangi } \\
\text { penganggur } \\
\text { an }\end{array}$ & 35 & $7 \%$ \\
\hline
\end{tabular}

Berdasarkan tabel di atas menunjukkan bahwa pada karakteristik responden berdasarkan jenis kelamin didominasi oleh Perempuan yaitu sebanyak 56\%. Pada karakteristik responden berdasarkan usia didominasi oleh usia $\leq 25$ Tahun yaitu sebanyak 45\%. Karakteristik responden berdasarkan status didominasi oleh mahasiswa yaitu sebanyak 53\%. Karakteristik responden berdasarkan lama interaksi didominasi $>1$ tahun yaitu sebanyak $72 \%$. Karakteristik responden berdasarkan lokasi pemesanan didominasi pelnggan sering melkukan pemesanan transformasi ketika mobile yaitu sebanyak 53\%. Karakteristik responden berdasarkan transportasi online yang sering digunakan didominasi oleh GOJEK yaitu sebanyak $82 \%$. Karakteristik responden berdasarkan fasilitas yang sering digunakan persentasi tertinggi adalah GoRide sebanyak 42\%. Sedangkan karakteristik responden yang dilihat dari segi manfaat yang diperoleh dengan memanfaatkan transportasi online persentasi tertinggi adalah memiliki manfaat yaitu multifungsi sebanyak $33 \%$.

\subsection{Hasil Analisis Data}

1. Uji Asumsi Klasik

a. Uji Multikolinieritas Di bawah ini merupakan hasil uji multikolinieritas:

Tabel 6. Hasil Multikolinieritas

\begin{tabular}{|c|c|c|c|c|c|c|c|}
\hline \multicolumn{8}{|c|}{ Coefficients $^{\mathbf{a}}$} \\
\hline \multirow{3}{*}{$\begin{array}{l}\text { Model } \\
1 \text { (Constant) }\end{array}$} & $\begin{array}{l}\text { Unsta } \\
\text { ed } \\
\text { Coeffi }\end{array}$ & $\begin{array}{l}\text { dardiz } \\
\text { cients }\end{array}$ & $\begin{array}{l}\text { Stand } \\
\text { ardiz } \\
\mathrm{d} \\
\text { Coeft } \\
\text { cient }\end{array}$ & & & $\begin{array}{l}\text { Collin } \\
\text { Statist }\end{array}$ & $\begin{array}{l}\text { earity } \\
\text { ics }\end{array}$ \\
\hline & B & $\begin{array}{l}\text { Std. } \\
\text { Error }\end{array}$ & Beta & $\mathrm{t}$ & Sig. & $\begin{array}{l}\text { Toler } \\
\text { nce }\end{array}$ & VIF \\
\hline & 1.268 & .643 & & 1.972 & .049 & & \\
\hline SUMX1 & .126 & .013 & .492 & 9.740 & .000 & .414 & 2.416 \\
\hline SUMX2 & .333 & .049 & .340 & 6.736 & .000 & .414 & 2.416 \\
\hline
\end{tabular}

Berdasarkan tabel di atas memperlihatkan bahwa $\geq 0,10$ untuk nilai tolerance variable bebas 
(X) sebesar 0.414 dan VIF mempunyai nilai sebesar $\leq 10$. Hasil tersebut menunjukan bahwa seluruh varabel $\mathrm{X}$ dapat kita gunakan karena tidak ditemukannya korelasi bebas (bebas multikoloniertitas) dalam persamaan regresi. Akan tetapi, jika nilai tolerance dan VIF memiliki nilai sebaliknya, maka dapat disimpulkan bahwa multikolonieritas tidak terjadi pada seluruh variable bebas (X).

\section{b. Uji Heteroskedastisitas}

Hasil uji multikolinieritas dapat dilihat pada gambar 1 .

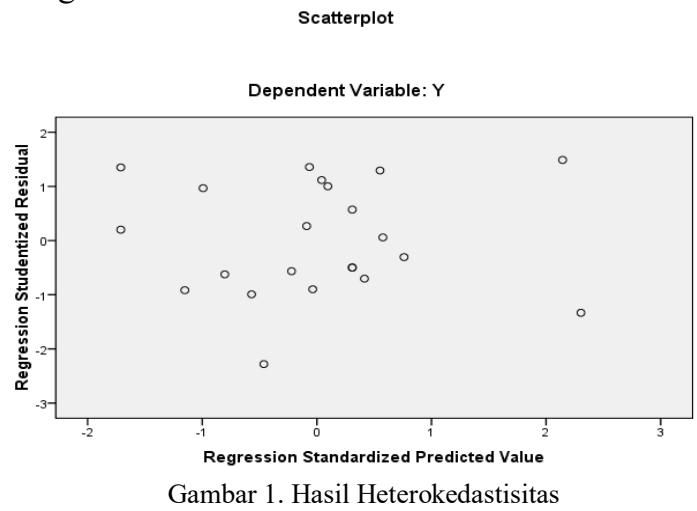

Pada hasil uji multikolinieritas. Pada saat melakukan uji heteroskedastisitas, dapat kita lihat bahwa sebaran titik-titik terlihat secara acak yaitu terletak di bawah 0 pada sumbu Y dan memperoleh kesimpulan bahwa tidak terjadinya heterokedastisitas. Sehingga, dalam melakukan prediksi terhadap variabel keputusan model regresi sangat layak digunakan berdasarkan variabel kualitas layanan dan variabel harga.

c. Uji Normalitas

Di bawah ini merupakan hasil uji Normalitas:

Tabel 7. Hasil Normalitas

\begin{tabular}{|c|c|c|}
\hline \multicolumn{3}{|c|}{ One-Sample Kolmogorov-Smirnov Test } \\
\hline & & $\begin{array}{l}\text { Unstandardized } \\
\text { Residual }\end{array}$ \\
\hline \multicolumn{2}{|l|}{$\mathrm{N}$} & 370 \\
\hline \multirow{2}{*}{$\begin{array}{l}\text { Normal } \\
\text { Parameters }\end{array}$} & Mean & .0000000 \\
\hline & Std. Deviation & 1.45623186 \\
\hline \multirow{3}{*}{$\begin{array}{l}\text { Most } \quad \mathrm{E} \\
\text { Differences }\end{array}$} & Extreme Absolute & .045 \\
\hline & Positive & .045 \\
\hline & Negative & -.045 \\
\hline \multicolumn{2}{|c|}{ Kolmogorov-Smirnov Z } & .872 \\
\hline \multicolumn{2}{|c|}{ Asymp. Sig. (2-tailed) } & .432 \\
\hline
\end{tabular}

Dari tabel 7. di atas menunjukkan bahwa terpenuhinya asumsi normalitas terhadap model persamaan regresi linier berganda dikarenakan hasil dari nilai Asymp. sig sebesar 0,432 > dari Unstandardized Residual 0,05. Sehingga, seluruh varibel dapat kita gunakan dalam proses penelitian. d. Uji Linieritas

Di bawah ini merupakan hasil uji Linieritas: Tabel 8. Hasil Linieritas

\begin{tabular}{lccccc}
\hline Model & $\mathbf{R}$ & $\begin{array}{c}\mathbf{R} \\
\text { Square }\end{array}$ & $\begin{array}{c}\text { Adjusted R } \\
\text { Square }\end{array}$ & $\begin{array}{c}\text { Std. Error } \\
\text { of the } \\
\text { Estimate }\end{array}$ & $\begin{array}{c}\text { Durbin- } \\
\text { Watson }\end{array}$ \\
\hline 1 & $.783^{\mathrm{a}}$ & .613 & .611 & 1.46019 & 1.955 \\
\hline
\end{tabular}

Dari tabel di atas memperoleh hasil uji linieritas bahwa dengan nilai Durbin Watson sebesar 1.955 dengan nilai sig $5 \%$ dari 370 resposden dengan varibel independen $2(\mathrm{k}=2)$. Dimana nilai tersebut lebih besar dari nilai (dL) yaitu 1.145, maka dapat ditarik sebuah kesimpulan bahwa penelitian ini memenuhi uji linearitas.

2. Analisis Regresi Linier Berganda

Hasil uji regresi linier berikut ini:

Tabel 9. Hasil Regresi Linier Berganda

\begin{tabular}{|c|c|c|c|c|c|c|}
\hline \multicolumn{7}{|c|}{ Coefficients $^{\mathrm{a}}$} \\
\hline \multirow[b]{2}{*}{ Model } & & \multicolumn{2}{|c|}{$\begin{array}{l}\text { Unstandardized } \\
\text { Coefficients }\end{array}$} & \multicolumn{2}{|l|}{$\begin{array}{l}\text { Standardized } \\
\text { Coefficients }\end{array}$} & \multirow[b]{2}{*}{ Sig. } \\
\hline & & B & Std. Error & Beta & $\mathrm{t}$ & \\
\hline \multirow[t]{3}{*}{1} & (Constant) & 1.268 & .643 & & 1.972 & .049 \\
\hline & SUMX1 & .126 & .013 & .492 & 9.740 & .000 \\
\hline & SUMX2 & .333 & .049 & .340 & 6.736 & .000 \\
\hline
\end{tabular}

Berdasarkan table 9. maka dapat diperoleh persamaan regresi linear berganda sebagai berikut:

$$
\mathrm{Y}=1,268+0,126 \mathrm{X}_{1}+0,333 \mathrm{X}_{2}
$$

Keterangan:

$\mathrm{Y}=$ Kepuasan pelanggan

$\mathrm{b} 2=0,333$

$\mathrm{a}=1,268$

$\mathrm{X} 1=\quad$ Kualitas

layanan

b1 $=0,126$

$\mathrm{X} 2=$ Harga

3. Koofisien Determinasi $\left(\mathrm{R}^{2}\right)$

Berikut ini adalah hasil koofisien determinasi:

Tabel 10. Hasil koofesien determinas

\begin{tabular}{|c|c|c|c|c|c|}
\hline $\begin{array}{c}\text { Mode } \\
\text { I }\end{array}$ & $\mathbf{R}$ & $\begin{array}{c}\mathbf{R} \\
\text { Square }\end{array}$ & $\begin{array}{c}\text { Adjusted } \\
\text { R } \\
\text { Square }\end{array}$ & $\begin{array}{c}\text { Std. Error } \\
\text { of the } \\
\text { Estimate }\end{array}$ & $\begin{array}{l}\text { Durbin- } \\
\text { Watson }\end{array}$ \\
\hline 1 & $.783^{\mathrm{a}}$ & .613 & .611 & 1.46019 & 1.955 \\
\hline
\end{tabular}

Dengan diperolehnya nilaikoefisien determinasi $\left(\mathrm{R}^{2}\right)$ sebesar 0,611 seperti yang diperlihatkan pada tabel di atas berarti kualitas layanan $\left(\mathrm{X}_{1}\right)$ dan harga $\left(\mathrm{X}_{2}\right)$ terhadap variabel kepuasan pelanggan (Y) jasa transportasi online sama artinya dengan $61,1 \%$ dan $38,9 \%$ sisanya merupakan pengaruh dari variabel lain yang tidak dijelaskan dan dibahas dalam penelitian ini. 
4. Uji Hipotesis

a. Uji t

Di bawah ini merupakan hasil uji $\mathrm{t}$

Tabel 11. Hasil Uji t

\begin{tabular}{|c|c|c|c|c|c|}
\hline \multicolumn{6}{|c|}{ Coefficients $^{\mathrm{a}}$} \\
\hline \multirow[b]{2}{*}{ Model } & \multicolumn{2}{|c|}{$\begin{array}{l}\text { Unstandardized } \\
\text { Coefficients }\end{array}$} & \multicolumn{2}{|l|}{$\begin{array}{l}\text { Standardized } \\
\text { Coefficients }\end{array}$} & \multirow[b]{2}{*}{ Sig. } \\
\hline & B & Std. Error & Beta & $\mathrm{t}$ & \\
\hline 1 (Constant) & 1.268 & .643 & & 1.972 & .049 \\
\hline SUMX1 & .126 & .013 & .492 & 9.740 & .000 \\
\hline SUMX2 & .333 & .049 & .340 & 6.736 & .000 \\
\hline
\end{tabular}

Dari hasil uji t di atas, diperoleh bahwa adanya hubungan secara parsial antara variabel kualitas layanan $\left(\mathrm{X}_{1}\right)$ terhadap kepuasan pelanggan (Y). Dimana nilai t hitung pada variabel $\left(\mathrm{X}_{1}\right)$ sebesar 9,740 dengan tingkat signifikan sebesar 0,000 yang hasilnya lebih kecil dari 0,05 atau 5\%, maka $\mathrm{H} 1$ diterima.

Selain itu, dari hasil uji $\mathrm{t}$ di atas diperoleh bahwa adanya hubungan parsial antara varibel harga $\left(\mathrm{X}_{2}\right)$ terhadap kepuasan pelanggan $(\mathrm{Y})$. Dimana nilai $\mathrm{t}$ hitung pada variabel $\left(\mathrm{X}_{2}\right)$ sebesar 6,736 dengan tingkat signifikansi sebesar $0,000<0,05$ atau 5\%, maka $\mathrm{H} 1$ diterima.

b. Uji F

Hasil uji F, dapat dilihat pada tabel 12. Dari table hasil uji $\mathrm{F}$, antara kedua variabel bebas $(\mathrm{X})$ memiliki pengaruh secara simultan terhadap kepuasan pelanggan (Y) jasa transportasi online di kota Palembang. Hai ini diperoleh dari nilai $\mathrm{F}$ hitung 290.810 dengan tingkat signifikansi 0,000 lebih kecil dari 5\%. Sehingga, H2 diterima.

Tabel 12. Hasil Uji F

\begin{tabular}{|c|c|c|c|c|c|}
\hline \multicolumn{6}{|c|}{ ANOVA $^{b}$} \\
\hline Model & $\begin{array}{l}\text { Sum of } \\
\text { Squares }\end{array}$ & Df & $\begin{array}{l}\text { Mean } \\
\text { Square }\end{array}$ & $\mathrm{F}$ & Sig. \\
\hline 1 Regression & 1240.113 & 2 & 620.057 & 290.810 & $.000^{\mathrm{a}}$ \\
\hline Residual & 782.506 & 367 & 2.132 & & \\
\hline Total & 2022.619 & 369 & & & \\
\hline
\end{tabular}

\subsection{Pembahasan}

\subsubsection{Pengaruh secara parsial antara variabel bebas $\left(X_{1}\right)$ dan $\left(X_{2}\right)$ terhadap kepuasan pelanggan $(\mathrm{Y})$ jasa transportasi online di Palembang.}

Dari hasil uji t yang telah dilakukan maka dapat kita lihat bahwa antara variabel $\left(\mathrm{X}_{1}\right)$ dan $\left(\mathrm{X}_{2}\right)$ memiliki pengaruh parsial secara signifikasi positif terhadap kepuasan pelanggan (Y). Dimana dari kedua variabel tersebut variabel hargalah yang memiliki kontribusi terbesar dibandingkan kualitas layanan. Berikut adalah penjelasan antar variabel:

1. Variabel Kualitas layanan berpengaruh signifikan terhadap kepuasan pelanggan jasa transportasi online di Palembang

Dengan nilai hasil perhitungan uji t yang telah dilakukan diperoleh sebuah nilai koefisien kualitas layanan sebesar 0,492 dengan nilai t hitung 9.740 dan tingkat signifikansi 0,000. Sehingga dapat disimpulkan bahwa dapat dinyatakan $\mathrm{H} 1$ diterima. Dimana kualitas layanan $\left(\mathrm{X}_{1}\right)$ berpengaruh secara signifikasi terhadap kepuasan pelanggan (Y). Menurut A. Atmadjati (2018), kualitas layanan adalah suatu kemampuan untuk memenuhi kebutuhan internal dan eksternal pelanggan secara konsisten sesuai prosedur. Kualitas jasa harus dimulai dari kebutuhan pelanggan dan berakhir dengan kepuasan pelanggan serta persepsi positif terhadap kualitas jasa.

Menurut E. S. Mamang (2013), untuk mempermudah penilaian dan pengukuran kualitas pelayanan dikembangkan suatu alat kualitas layanan yang disebut SERVQUAL (Service Quality) yang merupakan skala multi item yang dapat digunakan untuk mengukur persepsi pelanggan atas kualitas layanan meliputi lima dimensi yaitu tangibles, Reliability, responsiveness, Assurance, dan Empathy.

Dimensi yang pertama yaitu tangibles menggambarkan tentang bagaimana kondisi fasilitas, perlengkapan, peralatan dan penampilan seragam dari staf. Tangibles pada jasa transportasi online di Palembang dapat meliputi: bagaimana kondisi dari kendaraan yang digunakan apakah layak jalan dan tidak mengalami modifikasi, perlengkapan keamanan berkendara untuk digunakan oleh konsumen, pemggunaan identitas perusahaan, cara berpakaian pada saat proses pelayanan konsumen berlangsung.

Dimensi yang kedua, reliability merupakan kemampuan dalam melakukan pemberian pelayanan yang menjanjikan kepada konsumen secara akurat. Reliability yang diberikan oleh jasa transportasi online di Palembang meliputi: cepat melakukan konfirmasi secara jelas jika driver terlambat dalam melakukan pelayanan pada pelanggan, dalam mengemudikan kendaraan driver harus taat pada peraturan tata tertib berlalu lintas yang berlaku, tariff yang harus dibayar konsumen sesuai dengan harga yang tertera di aplikasi, memberikan pelayanan kepada konsumen tanpa mengenal waktu yaitu selama 24 jam dan memberikan kemudahan dalam melakukan order.

Ketiga, Responsiveness yang berarti kemampuan dalam memeberi bantuan, pelayanan yang cepat, dan memberikan perhatian yang penuh. Responsiveness dalam jasa transportasi online di Palembang dapat kita lihat dari beberapa hal diantaranya yaitu setiap order konsumen harus melakukan konfirmasi secara cepat dengan cara 
menghubungi konsumen guna memastikan mealui media handpone, jangan menunda kedatangan ke lokasi order agar pelanggan tidak menunggu lama dan meberikan pelayanan secara cepat jika pelanggan mengalami keluhan dan kendala.

Keempat, Assurance dapat diartikan sebagai sebuah kemampuan yang dimiliki oleh staf dalam segi pengetahuan dan memiliki kesopanan guna memberikan inspirasi berupa kepercayaan dan keyakinan. Assurance dalam jasa transportasi online di Palembang dapat dilihat dari terampil seorang driver dalam mengendalikan kendaraan mereka, memiliki pengetahuan sejumlah informasi lokasi jalan atau alamat yang dituju dan memberikan fasilatas layanan untuk melakukan pengaduan pada aplikasi.

Kelima, Empathy dapat diartikan sebagai kepedulian yang diperlihatkan oleh staf, memberikan perhatian khusus, dan dari segi penampilan yang diperlihatkan oleh staf. Empathy pada jasa transportasi online di Palembang, meliputi: harus menciptakan rasa nyaman pada setiap pelanggan, driver memberi bantuan dalam mengangkut dan menaikkan barang jika pelanggan mengalami kendala, memberikan bantuan kepada pelanggan saat akan menaiki kendaraan driver online, menjelaskan cara penggunaan helm yang tepat pada pelanggan khususnya pelanggan sepeda motor.

Menurut Tjiptono dan dkk (2008), pengalaman dapat diartikan sebagai faktor yang akan melihat pengaruh terhadap pelanggan apakah seorang pelanggan merasa puas atau tidak terhadap produk atau jasa yang dibeli. Menurut E. S. Mamang (2013), Kualitas pelayanan berkaitan erat dengan kepuasan pelanggan. Kualitas pelayanan memberikan dorongan khusus bagi para pelanggan untuk menjalin ikatan relasi saling menguntungkan dalam jangka panjang dengan perusahaan. Dari paparan di atas menunjukkan bahwa sebuah layanan sangat diperlukan dalam membentuk kepuasan pelanggan, karena semakin baik pengalaman yang dirasakan pelanggan pada saat menggunakan sebuah jasa maka kepuasan yang dirasakan pelanggan akan semakin tinggi.

Y. Pratama (2015), kualitas layanan memiliki pengaruh yang signifikan terhadap kepuasan pelanggan, semakin baik kualitas layanan yang diberikan, maka semakin tinggi kepuasan pelanggan terhadap layanan tersebut. Berdasarkan pernyataan di atas dapat ditarik sebuah kesimpulan bahwa kualitas layanan mempengaruhi kepuasan pelanggan jasa transportasi online di Palembang.

2. Harga berpengaruh terhadap kepuasan pelanggan jasa transportasi online di Palembang

Hasil perhitungan uji t menunjukkan nilai koefisien kualitas layanan 0,340 dengan nilai t hitung 6.736 dan tingkat signifikansi 0,000. Dari hal ini dapat diketahui bahwa harga $\left(\mathrm{X}_{2}\right)$ berpengaruh terhadap kepuasan pelanggan (Y), dengan ini dapat dinyatakan bahwa $\mathrm{H} 1$ diterima.

Menurut Kaihatu dan dkk (2015), harga adalah sejumlah uang yang bersedia dibayarkan oleh seorang konsumen untk mendapatkan barang atau jasa tertentu. Salah satu faktor kepuasan pelanggan dapat diperoleh melalui penetapan harga yang tepat. Harga merupakan salah satu unsure pemasaran yang terpenting dan turut mempengaruhi keputusan pelanggan untuk membeli.

Berikut ini adalah kondisi harga pada jasa transportasi online di Palembang yang meliputi: harga/tarif transportasi online dapat dijangkau oleh pelanggan, harga/tarif transportasi online dapat bersaing dengan penyedia transportasi layanan transportasi konvensional, harga/tarif transportasi online sesuai dengan manfaat yang didapatkan pelanggan, harga/tarif transportasi online sesuai dengan fasilitas keselamatan yang di sediakan untuk pelanggan.

Hal ini sesuai dengan hasil penelitian yang dilakukan oleh T. H. handayani (2013), yang menunjukkan bahwa harga memiliki pengaruh yang signifikan terhadap kepuasan pelanggan Hasil penelitian yang dilakukan Reinhard, dkk (2014) menunjukkan bahwa harga berpengaruh terhadap kepuasan pelanggan.

\subsubsection{Pengaruh secara simultan kualitas layanan $\left(X_{1}\right)$ dan harga $\left(X_{2}\right)$ terhadap kepuasan pelanggan (Y) jasa transportasi online di Palembang.}

Hasil penelitian berdasarkan uji ANOVA, menunjukkan F hitung sebesar 290.810 dengan taraf signifikansi 0,000 yang lebih kecil dari 0,05 atau 5\%. Maka dapat diketahui bahwa kualitas layanan $\left(\mathrm{X}_{1}\right)$ dan harga $\left(\mathrm{X}_{2}\right)$ secara bersama-sama berpengaruh terhadap kepuasan pelanggan (Y).

Berdasarkan nilai koefisien determinasi yang ditunjukkan dengan nilai Adjusted R Square sebesar 0,611 yang berarti bahwa $61,1 \%$ yang dapat dijelaskan oleh variabel bebas (kualitas layanan dan harga) dari kepuasan pelanggan (Y). Sedangkan sisanya $38,9 \%$ dipengaruhi oleh variabel-variabel lain yang tidak ada di dalam penelitian ini, seperti emotional factor, kemudahan, komunikasi melalui iklan, pengalaman dari teman, dan kebutuhan dan keinginan.

Dari hasil pemaparan penelitian di atas dapat disimpulakn bahwa H2 diterima. Dapat disimpulkan bahwa variabel kualitas layanan dan harga memiliki pengaruh secara simultan (bersamasama) terhadap kepuasan pelanggan jasa transpotasi online di Palembang. Dari dua variabel bebas (indepeden) yaitu kualitas layanan dan harga yang paling dominan dalam mempengaruhi kepuasan pelanggan adalah kualitas layanan dengan koefisien 0 , 492. Sedangkan variabel berikutnya yang memiliki peran lebih kecil dalam mempengaruhi 
kepuasan pelanggan adalah harga dengan koefisien 0.340 .

Apabila pelanggan merasa puas pada kualitas layanan dan harga yang diberikan, maka pelanggan akan menunjukkan besarnya kemungkinan melakukan pembelian ulang pada produk tersebut. Menurut Kotler (2009), pelanggan yang puas juga akan cenderung memberikan komentar yang baik terhadap produk atau jasa dan perusahaan serta merekomendasikan produk kepada orang lain. Sedangkan jika kualita produk dan harga yang di dapatkan pelanggan kurang baik ataupun buruk akan menimbulakn ketidakpuasan pada pelanggan, karena pelanggan yang kecewa akan bercerita kepada orang lain. tidak hanya berdampak pada pelanggan yang pernah menggunakan jasa transportasi online tersebut melainkan berdampak juga bagi calon pelanggan sehingga menjatuhkan pilihannya kepada jasa transportasi online pesaing yang dianggap lebih mampu memenuhi keinginan dan kepuasan mereka.

Hal ini sejalan dengan penelitian terdahulu yang dilakukan oleh Handayani (2013) yang menyimpulkan bahwa kualitas layanan dan harga secara simultan berpengaruh terhadap kepuasan pelanggan. Penelitian Reinhard, dkk (2014) juga menunjukkan ada pengaruh antara kualitas layanan dan harga secara simultan (bersama-sama) terhadap kepuasan pelanggan. Pratama (2015), juga menunjukkan kualitas layanan, harga, fasilitas terhadap kepuasan pelanggan.

\section{KESIMPULAN}

Berdasarkan hasil penelitian tentang pengaruh kualitas layanan dan harga terhadap kepuasan pelanggan jasa transportasi online di Palembang, maka ditarik beberapa kesimpulan sebagai berikut:

1. Dari hasil penelitian yang telah dilakukan dapat diketahui bahwa variabel kualitas layanan $\left(\mathrm{X}_{1}\right)$ mempunyai pengaruh yang signifikan secara parsial terhadap variabel terikat yaitu kepuasan pelanggan (Y) jasa transportasi online di Palembang. Variabel harga $\left(\mathrm{X}_{2}\right)$ mempunyai pengaruh yang signifikan secara parsial terhadap variabel terikat yaitu kepuasan pelanggan (Y) jasa transportasi online di Palembang dan variabel kualitas layanan (X1) memiliki pengaruh yang lebih dominan.

2. Dari hasil penelitian yang telah dilakukan dapat diketahui bahwa variabel kualitas layanan dan harga mempunyai pengaruh yang signifikan dan bersama-sama (simultan) terhadap variabel terikat yaitu kepuasan pelanggan jasa transportasi online di Palembang.

\section{DAFTAR PUSTAKA}

KURNIATI., 2018. Pengembangan Digital Library Universitas Bina Darma Menggunakan
Pendekatan Human Computer Interaction. Jurnal Rekayasa Sistem dan Teknologi Informasi (RESTI), 2(2), pp. 542 553.

SANTIARI, P. \& RAHAYUDA. I., 2018. Analisis Kualitas Website Alumni Stikom Bali Menggunakan Metode Webqual. Jurnal Teknologi Informasi dan Ilmu Komputer (JTIIK), 5(2), pp. 231-238

WAJIYONO \& MEI.C.H., 2018. Pengukuran Kualitas Website Pemerintah Desa Jagalempeni Menggunakan Metode Webqual 4.0. Jurnal Teknologi Informasi dan Ilmu Komputer (JTIIK), 5(2), pp. 139146.

SUGIYONO., 2014. Metode Penelitian Bisnis. Bandung: Alfabeta.

SAEPUL, A. H., 2014 Metode Penelitian Kuantitatif aplikasi dan Pendidikan. Yogyakarta: Deepublish.

PUTRO, E. W., 2013. Teknik penyusunan Instrumen Penelitian.Yogyakarta: Pustaka Pelajar.

GHOZALI. I., 2013 Aplikasi Analisis Multivariate dengan Program SPSS Cetakan VII. Semarang: Badan penerbit Universitas Diponegoro.

ATMADJATI. A., 2018. Layanan Primadalam Praktik Saat Ini. Yogyakarta: Deepublish.

MAMANG. E. S., 2013. Prilaku Konsumen, Yogyakarta: Andi.

TJIPTONO. F.,dkk, 2008. Pemasaran Strategik. Yogyakarta: Andi Offset.

PRATAMA. Y., 2015. "pengaruh harga dan Kualitas Pelayanan Terhadap Kepuasan Konsumen Po. rosalia indah Di Palur Karanganyar dengan Fasilitas sebagai Variabel Moderasi," Jurnal ekonomi dan Kewirausahaan, vol. 15, no. Pengaruh signifikan kualitas layanan dan harga pada kepuasan konsumen Po. Rosalia, pp. 181188.

KAIHATU dan dkk, 2015. Manjemen Komplain. Yogyakarta: Andi.

HANDAYANI. T. H., 2013. "pengaruh harga dan Kualitas Pelayanan Terhadap Kepuasan Pelanggan Penerbangan Garuda Indonesia di Kota Solo," Universitas Muhammadiyah, Surakarta.

REINHARD, AGUS HERMANI DAN ANDI WIJAYANTO, 2013. "pengaruh harga dan Kualitas Pelayanan Terhadap Kepuasan Pelanggan ( Studi pada Penumpang Kereta Api kelas Argo jurusan Semarang-Jakarta PT KAI DAOP IV Semarang," Administrasi Bisnis, vol. 2, no. Pengaruh Kualitas Layanan dan harga terhadap kepuasan pelanggan PT KAI Jurusan Semarang-Jakarta, pp. 127-135. 